\title{
Safety and Toxicity of Catheter Gene Delivery to the Pulmonary Vasculature in a Patient with Metastatic Melanoma
}

\author{
ELIZABETH G. NABEL, ${ }^{1}$ ZHIYONG YANG,${ }^{1,6}$ DAVID MULLER,${ }^{1}$ ALFRED E. CHANG,${ }^{2}$ XIANG GAO, ${ }^{3}$ \\ LEAF HUANG,${ }^{3}$ KYUNG J. CHO ${ }^{4}$ and GARY J. NABEL ${ }^{1,5,6}$
}

\begin{abstract}
One approach to gene therapy for human cancer is transcatheter injection of DNA liposomes into tunor masses. To determine the feasibility of selective delivery of recombinant genes by a catheter to the pulmonary vasculature in humans, a patient with melanoma received two treatınents of HLA-B7 plasinid DNA complexed to cationic liposomes into a right posterior basal pulmonary artery associated with a mass lesion. The treatnents were well tolerated. No adverse respiratory, cardiac, immunologic, or otler organ toxicities were detected. The delivery of recombinant genes by catheter may be a useful modality to treat human malignancy and other diseases.
\end{abstract}

\section{OVERVIEW SUMMARY}

Transcatheter delivery of HLA-B7 DNA and cationic liposomes into a segment of a pulmonary artery was safely performed in 1 patient with tumor nodules in the lung. No immunologic or organ toxicities were observed. Percutaneous catheter gene delivery has been performed in humans. Further refinements of this approach may lead to useful treatments for a variety of human diseases.

\section{INTRODUCTION}

O NE APPROACH TO CANCER IMMUNOTHERAPY is the direct transmission of recombinant genes into established tumors to modulate the immune response directed against tumor growth (Plautz et al., 1993). Recombinant genes can be directly introduced into tumors by injection of subcutaneous tumor nodules or by catheter delivery into the vasculature of parenchymal masses (Nabel et al., 1993a). Therapeutic drugs are routinely delivered to selective sites in the circulation by catheters to treat vascular diseases (Kennedy et al., 1985; Ambrose et al., 1992) and parenchymal tumors (Ensminger, 1993). Transcatheter introduction of recombinant genes and vectors to selective re- gions of the vasculature has been established in preclinical animal models (Nabel et al., 1990; LeClerc et al., 1992; Barr et al., 1994), but the toxicities and safety of catheter-based gene delivery in humans has not been explored. We report here the delivery of a class I major histocompatibility complex (MHC) gene in cationic liposomes by transcatheter injection into the right posterior basal pulmonary artery and surrounding right lower lobe tumor mass in a patient enrolled in a human gene therapy protocol for immunotherapy of melanoma. The findings suggest that transcatheter delivery of genetic material in this patient appears safe and well tolerated. This approach may be applicable to the genetic treatment of cancer and vascular diseases.

\section{MATERIALS AND METHODS}

Informed consent was obtained according to the Committee to Review Grants for Clinical Research and Investigations Involving Human Beings of the University of Michigan Medical School, the Recombinant DNA Advisory Committee of the National Institutes of Health, and the Food and Drug Administration.

Departments of ${ }^{1}$ Internal Medicine, ${ }^{2}$ Surgery, ${ }^{4}$ Radiology, and ${ }^{5}$ Biological Chemistry, ${ }^{6}$ Howard Hughes Medical Institute, University of Michigan Medical Center, Ann Arbor, MI 48109-0688.

${ }^{3}$ Department of Pharmacology, University of Pittsburgh School of Medicine, Pittsburgh, PA 15261. 


\section{Vector production}

A eukaryotic expression vector plasmid, pHLA-B7, was prepared by insertion of an HLA-B7 cDNA into the Rous sarcoma virus $\beta$-globin plasmid as previously described (Nabel et al., 1993a). HLA-B7 DNA-liposome complexes were prepared just prior to catheterization by adding $0.1 \mathrm{ml}$ of lactated Ringer solution into a sterile vial of HLA-B7 plasmid DNA $(20 \mu \mathrm{g} / \mathrm{ml}$; $0.1 \mathrm{ml})$. An aliquot of this solution $(0.1 \mathrm{ml})$ was added to $0.1 \mathrm{ml}$ of $150 \mu M$ dioleoyl phosphatidylethanolamine/3b- $\left[N-N^{\prime}, N^{\prime}\right.$ dimethylaminoethane) carbamoyl] cholesterol liposome (Gao and Huang, 1991) in lactated Ringer solution in a separate sterile vial. The solution was allowed to incubate for $15 \mathrm{~min}$ at room temperature, and $0.5 \mathrm{ml}$ of sterile lactated Ringers was added to the vial and mixed. The DNA, liposomes, and sterile vials were prepared in accordance with Food and Drug Administration guidelines and quality control procedures, as has been previously described (Nabel et al., 1993a).

\section{Gene transfer}

Percutaneous right heart catheterization was performed from the right femoral vein using sterile techniques. An 8 French sheath was inserted into the right femoral vein, and a 7 French Van Aman pigtail catheter was advanced into the right pulmonary artery under fluoroscopic guidance. After pressure measurement, selective catheterization of the right posterior basal segment artery was performed, and the Van Amen catheter was exchanged for a 5 French occlusion balloon catheter (MediTech, Watertown, MA) over a 0.025 -inch exchange guidewire. After balloon inflation, digital subtraction angiography was performed to confirm catheter position and arrest of blood flow (Fig. 1). Confirmation that blood flow was arrested was determined by inflation of the balloon and injection of intravenous contrast dye into the vascular space. No diffusion of the contrast material was noted over a 5-min period, thus ensuring that delivery of DNA and liposomes would proceed antegrade in the vasculature and not immediately admix with blood to inactivate the DNA-liposome complex. The posterior basal segment artery was rinsed with $30 \mathrm{ml}$ of sterile saline, and the HLA-B7 DNA-liposome solution, $1.43 \mu \mathrm{g}$ of DNA in a volume of 0.6 $\mathrm{ml}$, was instilled followed by an additional $1.0 \mathrm{ml}$ of sterile saline. This solution was injected through the end hole of the catheter into the posterior basal segment artery. An additional $3.0 \mathrm{ml}$ of sterile saline was instilled through the catheter, and the HLA-B7 DNA-liposome solution incubated for $20 \mathrm{~min}$ to achieve transduction of the local microcirculation. The balloon was deflated, and the catheter and femoral sheath were removed.

\section{Hemodynamic and biochemical monitoring}

To determine the effects of DNA-liposome delivery to the pulmonary vasculature, hemodynamic and biochemical monitoring was performed. The patient's electrocardiogram (ECG) (six-lead) was continuously recorded prior to, during, and after injection of the DNA-liposome solution. Pulmonary artery, pulmonary capillary wedge pressure, and systemic blood pressure were measured $5 \mathrm{~min}$ prior to gene transfer and 20 min after delivery of DNA and liposomes. Biochemical para-

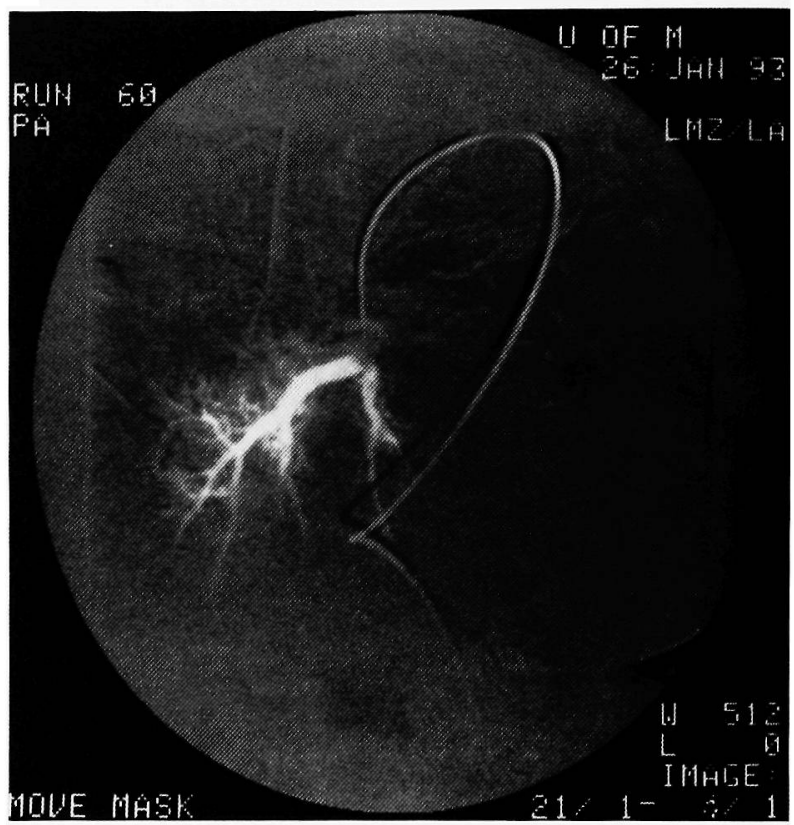

FIG. 1. Digital subtraction angiography of right posterior basal segment artery. After selective catheterization of the right posterior basal artery, a digital subtraction angiogram was performed. The intravenous contrast agent demonstrates displacement of the posterior basal segmental arteries by the tumor. The contrast agent was removed by instillation of $30 \mathrm{ml}$ of sterile saline solution followed by the introduction of $1.43 \mu \mathrm{g}$ of pHLA-B7 plasmid DNA complexed to DC-cholesterol liposome.

meters were also measured 1 day before and 1 day after each treatment.

\section{RESULTS}

A 68-year-old male with stage IV metastatic melanoma was enrolled in a human gene therapy clinical protocol. "Immunotherapy of malignancy by in vivo gene transfer into tumors" (Nabel et al., 1992), based upon clinical guidelines. This patient had undergone previous treatment for his melanoma, including a wide local excision, lymph node dissection, chemotherapy with DTIC, cis-platinum, and tamoxifen, BCG and IL-2 immunotherapy, interferon- $\gamma$ (IFN- $\gamma$ ) immunotherapy, and radiation. The patient was refractory to these treatments, and had recurrent melanoma on the chest wall and back, axillary lymph nodes, and lungs, confirmed by biopsy, thoracentesis, and post mortem examination. This patient was HLA-B $7^{-}$, $\mathrm{HLA}^{-}{ }^{+}$, and haplotype B5, 57, and $\mathrm{W}^{+}{ }^{+}$

The patient received two courses of HLA-B7 gene treatment by direct intratumor injection into cutaneous melanoma nodules on the left lower chest (treatment \#1) and left upper chest (treatment \#2). He responded to these treatments, showing complete regression of both treated nodules, as well as a $3-\mathrm{cm}$ pulmonary nodule (Nabel et al., 1993a). No evidence of toxicity was observed in this patient or any others studied in this trial (Table 1; see also Nabel et al., 1993a). However, the patient 
Table 1. Biochemical Parameters in Treated Patients

\begin{tabular}{|c|c|c|c|c|c|c|}
\hline & & & EMA & ATOL & OGY & \\
\hline & Day & HCT & WBC & PLT & PT & $P T T$ \\
\hline Pt. 1 & 0 & 44.2 & 6.9 & 225.0 & 11.7 & 21.6 \\
\hline & 2 & 40.4 & 6.0 & 205.0 & & \\
\hline & 14 & 39.5 & \begin{tabular}{l|}
6.6 \\
\end{tabular} & 241.0 & 11.5 & 21.8 \\
\hline & 28 & 41.7 & 6.3 & 171,0 & & \\
\hline & 56 & 43.3 & 6.2 & 246.0 & 11.7 & 24.2 \\
\hline P. 2 & 0 & 46.1 & 5.5 & 224.0 & \begin{tabular}{|l|}
11.1 \\
\end{tabular} & 22.4 \\
\hline & 2 & 46.8 & \begin{tabular}{l|l|}
8.9 \\
\end{tabular} & 210.0 & & \\
\hline & 14 & 45.8 & 6.2 & 334.0 & \begin{tabular}{|l|}
10.9 \\
\end{tabular} & 22.8 \\
\hline & 28 & 43.4 & 5.6 & 232.0 & 11.3 & 22.2 \\
\hline & 56 & 45.0 & 6.9 & 206.0 & \begin{tabular}{|l|l|}
11.3 \\
\end{tabular} & 22.6 \\
\hline$P_{1.3 A}$ & 0 & 30.9 & 4.5 & 215.0 & \begin{tabular}{|l|}
11.4 \\
\end{tabular} & \begin{tabular}{|l|l}
21.8 \\
\end{tabular} \\
\hline & 2 & 32.3 & 5.2 & 217.0 & & \\
\hline & 14 & 29.8 & $\begin{array}{l}6.5 \\
\end{array}$ & & 31.6 & 29.8 \\
\hline & 28 & 34.9 & 7.6 & 200.0 & 11.4 & 22.1 \\
\hline & 56 & 33.8 & 5.6 & \begin{tabular}{|l|}
264.0 \\
\end{tabular} & 11.5 & 22.6 \\
\hline Pt.3B & 0 & 32.8 & 6.4 & 240.0 & 11.6 & \begin{tabular}{|l|l}
22.2 \\
\end{tabular} \\
\hline & 2 & 30.5 & 6.3 & \begin{tabular}{|l|l}
195.0 \\
\end{tabular} & & \\
\hline & 14 & 31.3 & 8.3 & 227.0 & 11.9 & 21.5 \\
\hline & 28 & 32.6 & 5.4 & \begin{tabular}{|l}
221.0 \\
\end{tabular} & 11.5 & 21.8 \\
\hline & 58 & 32.3 & 5.0 & 202.0 & 11.7 & \begin{tabular}{|l|l}
21.3 \\
\end{tabular} \\
\hline Pt. 4 & 0 & 36.5 & 6.3 & 207.0 & \begin{tabular}{|l|}
11.0 \\
\end{tabular} & 21.9 \\
\hline & 2 & 39.0 & 7.3 & 181.0 & & \\
\hline & 14 & 37.2 & 7.2 & 242.0 & 11.5 & 22.3 \\
\hline & 28 & 35.9 & 7.4 & 183.0 & 12.1 & \begin{tabular}{|l}
21.9 \\
\end{tabular} \\
\hline & 56 & 37.6 & 7.7 & 205.0 & 12.2 & 21.6 \\
\hline P.. 5 & 0 & 34.7 & 7.4 & 290.0 & 12.4 & 24.5 \\
\hline & 2 & 34.6 & 5.1 & 268.0 & & \\
\hline & 14 & 32.3 & 4.2 & 319.0 & 11.9 & 25.8 \\
\hline & 28 & 28.5 & 4.4 & 274.0 & 11.9 & 24.5 \\
\hline & 56 & 33.1 & 7.4 & 403.0 & \begin{tabular}{|l|l|} 
\\
\end{tabular} & \begin{tabular}{|l}
27.1 \\
\end{tabular} \\
\hline
\end{tabular}

\begin{tabular}{|c|c|c|c|c|c|c|c|c|c|c|c|}
\hline \multicolumn{10}{|c|}{ CHEMISTRY } \\
\hline Na & K & CL & CO2 & BUN & CR & AST & ALT & LDH & CPK & AMY & LIP \\
\hline 134.0 & 3.5 & 96.0 & 26.0 & 11.0 & 0.6 & 35.0 & 56.0 & 197.0 & 47.0 & 67.0 & \\
\hline 135.0 & 3.5 & 96.0 & 33.0 & 12.0 & 0.7 & 30.0 & 45.0 & 214.0 & & & \\
\hline 139.0 & 3.5 & 98.0 & 32.0 & 20.0 & 0.7 & 44.0 & 59.0 & 205.0 & 47.0 & 71.0 & 44.0 \\
\hline 135.0 & 3.7 & 97.0 & 27.0 & 14.0 & 0.6 & 44.0 & 57.0 & 210.0 & & & \\
\hline 136.0 & 3.5 & 93.0 & 30.0 & 17.0 & 0.6 & 57.0 & 74.0 & 215.0 & & 96.0 & 136.0 \\
\hline
\end{tabular}

\begin{tabular}{|l|l|l|l|l|l|l|l|l|l|l|l|}
\hline 136.0 & 3.5 & 93.0 & 30.0 & 17.0 & 0.6 & 57.0 & 74.0 & 215.0 & & 96.0 & 136.0 \\
\hline
\end{tabular}

\begin{tabular}{|c|c|c|c|c|c|c|c|c|c|c|c|}
\hline \hline 138.0 & 4.0 & 94.0 & 34.0 & 3.0 & 0.6 & 54.0 & & & & & \\
\hline 139.0 & 4.6 & 98.0 & 25.0 & 8.0 & 0.5 & 25.0 & 21.0 & 232.0 & $<20.0$ & 54.0 & 20.0 \\
\hline 138.0 & 3.8 & 91.0 & 36.0 & 8.0 & 0.6 & 23.0 & 22.0 & 147.0 & & 46.0 & 16.0 \\
\hline 140.0 & 4.2 & 97.0 & 32.0 & 6.0 & 0.6 & 10.0 & & & & & \\
\hline 134.0 & 3.9 & 92.0 & 33.0 & 4.0 & 0.5 & 10.0 & 17.0 & 158.0 & & 33.0 & 4.0 \\
\hline
\end{tabular}

\begin{tabular}{|r|r|r|r|r|r|r|r|r|r|r|r|}
\hline 140.0 & 4.3 & 100.0 & 31.0 & 25.0 & 1.2 & 21.0 & 25.0 & 254.0 & $<20.0$ & 78.0 & 28.0 \\
\hline 140.0 & 4.2 & 103.0 & 31.0 & 26.0 & 1.0 & 18.0 & 22.0 & 265.0 & $<20.0$ & 63.0 & 12.0 \\
\hline 140.0 & 4.6 & 104.0 & 32.0 & 30.0 & 1.4 & 13.0 & 20.0 & 213.0 & & 95.0 & 16.0 \\
\hline 141.0 & 4.6 & 103.0 & 30.0 & 30.0 & 1.1 & 20.0 & 20.0 & 258.0 & & 123.0 & 18.0 \\
\hline 140.0 & 4.3 & 100.0 & 29.0 & 31.0 & 1.1 & 19.0 & 21.0 & 278.0 & & 73.0 & 11.0 \\
\hline
\end{tabular}

\begin{tabular}{|r|r|r|r|r|r|r|r|r|r|r|r|}
\hline \hline 141.0 & 4.5 & 104.0 & 31.0 & 32.0 & 1.3 & 24.0 & 23.0 & 239.0 & & 93.0 & 16.0 \\
\hline 145.0 & 4.5 & 109.0 & 28.0 & 23.0 & 1.0 & 15.0 & 14.0 & 278.0 & $<20.0$ & 69.0 & 12.0 \\
\hline 139.0 & 4.2 & 102.0 & 28.0 & 31.0 & 1.1 & 8.0 & 15.0 & 241.0 & & 81.0 & 14.0 \\
\hline 142.0 & 4.0 & 106.0 & 28.0 & 29.0 & 1.3 & 14.0 & 21.0 & 257.0 & & 84.0 & 30.0 \\
\hline 143.0 & 4.1 & 107.0 & 24.0 & 24.0 & 1.1 & 28.0 & 28.0 & 251.0 & & 104.0 & 52.0 \\
\hline
\end{tabular}

\begin{tabular}{|r|r|r|r|r|r|r|r|r|r|r|r|}
\hline \hline 139.0 & 3.9 & 104.0 & 27.0 & 10.0 & 1.0 & 19.0 & 12.0 & 215.0 & & $<30.0$ & 40.0 \\
\hline 139.0 & 3.9 & 99.0 & 26.0 & 13.0 & 0.9 & 33.0 & 20.0 & 544.0 & & $<30.0$ & 5.0 \\
\hline 142.0 & 4.2 & 102.0 & 28.0 & 17.0 & 1.1 & 13.0 & 25.0 & 357.0 & & & \\
\hline 139.0 & 4.0 & 102.0 & 30.0 & 12.0 & 1.0 & 30.0 & 27.0 & 520.0 & & $<30.0$ & 26.0 \\
\hline 138.0 & 4.1 & 96.0 & 30.0 & 7.0 & 1.0 & 28.0 & 24.0 & 666.0 & & $<30.0$ & 18.0 \\
\hline
\end{tabular}

\begin{tabular}{|c|c|c|c|c|c|c|c|c|c|c|c|}
\hline 139.0 & 4.3 & 98.0 & 28.0 & 14.0 & 0.9 & 41.0 & & & $<20.0$ & 47.0 & 18.0 \\
\hline 141.0 & 4.3 & 101.0 & 28.0 & 14.0 & 0.8 & 33.0 & 27.0 & 205.0 & $<20.0$ & 43.0 & 18.0 \\
\hline 141.0 & 4.2 & 102.0 & 26.0 & 13.0 & 0.9 & 37.0 & 24.0 & 262.0 & & 36.0 & 24.0 \\
\hline 142.0 & 4.7 & 104.0 & 29.0 & 15.0 & 0.9 & 39.0 & 26.0 & 284.0 & & 30.0 & 16.0 \\
\hline 139.0 & 3.9 & 97.0 & 26.0 & 14.0 & 0.8 & 48.0 & 22.0 & 473.0 & & 34.0 & 18.0 \\
\hline
\end{tabular}
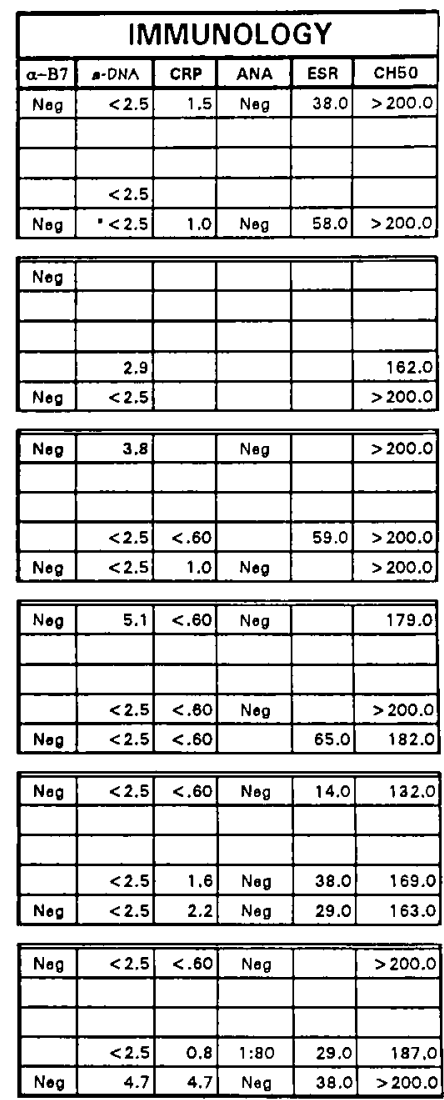

Hematology, chemistry, and immunology toxicity profiles of patients treated by gene transfer of HLA-B7. Pt. 3 refers to the subject described in the present report. Five patients with stage IV melanoma refractory to all available therapies were enrolled based on guidelines of the clinical protocol (Nabel et al., 1992a, 1993a). These patients were HLA-B7 negative, greater than 18 years of age, HIV negative, and infertile. Blank spaces indicate that values were not determined.

had at least two unresponsive pulmonary lesions, including a large right lower lobe mass identified by analysis of anteriorposterior and lateral views on chest film and computerized tomography of the chest. This mass was associated with the right posterior basal artery. Based on his previous reponse to this treatment, we considered the possibility of delivering the recombinant gene to the pulmonary nodule by catheterization. Permission to perform this procedure was sought and obtained from the Recombinant DNA Advisory Committee and the Food and Drug Administration.

Informed consent was obtained from the patient, and the patient underwent two percutaneous transcatheter treatments to the right posterior basal artery, 2 weeks apart (Fig. 1). During each treatment, $0.6 \mathrm{ml}$ of DNA-liposome solution was administered followed by an additional total of $4 \mathrm{ml}$ of sterile saline to distribute it to the local microcirculation. Both treatments were well tolerated, without acute complications. There were no ECG abnormalities or arrhythmias during both treatments. Analysis of hemodynamic parameters revealed no
Table 2. Systemic and Pulmonary Hemodynamic MEASUREMENTS DURING PUlmonary ARTERY GENE TRANSFER

\begin{tabular}{lcclccc}
\hline & \multicolumn{2}{c}{ Treatment 1 } & & \multicolumn{2}{c}{ Treatment 2 } \\
\cline { 2 - 3 } \cline { 6 - 6 } & Pre & Post & & Pre & Post \\
\hline $\begin{array}{c}\text { Systemic blood pressure } \\
\text { (mm Hg) }\end{array}$ & $121 / 71$ & $128 / 76$ & & $111 / 74$ & $116 / 78$ \\
$\begin{array}{c}\text { Pulmonary artery pressure } \\
\text { (mmHg) }\end{array}$ & $28 / 8$ & $27 / 8$ & & $22 / 4$ & $23 / 5$ \\
$\begin{array}{c}\text { Pulmonary capillary wedge } \\
\text { pressure (mean) (mmHg) }\end{array}$ & 15 & 16 & & 10 & 11 \\
\hline
\end{tabular}

Hemodynamic measurements of systemic and pulmonary artery pressures $5 \mathrm{~min}$ prior to and $20 \mathrm{~min}$ after catheter delivery of DNAliposomes into the right posterior basal segment artery. 
changes in pulmonary artery, pulmonary capillary wedge, or systemic arterial pressures measured $5 \mathrm{~min}$ before and $20 \mathrm{~min}$ after transcatheter injection (Table 2). The pulmonary artery pressure remained at $28 / 8 \mathrm{mmHg}$ (treatment \#1), and $22 / 4$ mmHg (treatment \#2), and the pulmonary capillary wedge pressure was 15 and $10 \mathrm{mmHg}$ during treatments 1 and 2 , respectively.

Analysis of hematological and biochemical parameters revealed no systemic abnormalities in this patient, including measures of liver, renal, pancreatic, and cardiac function prior to or after the two transcatheter gene deliveries. Serum blood samples obtained during the pulmonary artery infusion were analyzed by the polymerase chain reaction (PCR) for the presence of plasmid DNA. In this patient, plasmid DNA was not detected in systemic blood during either treatment (sensitivity $<2 \mathrm{pg}$ / $\mathrm{ml}$ ). Myocardial abnormalities were not detected by analysis of creatine kinase in the serum of this patient prior to, during, or after the treatments. Likewise, no anti-DNA antibodies were detected in the patient (Table 3). Two weeks following the second treatment, a lung biopsy was considered but was not performed due to poor respiratory status of the patient. A right pleural thoracentesis was performed to relieve a chronic pleural effusion from this lung. Cytologies revealed that the lesion represented a second independent malignancy, an adenocarcinoma, in the right lung distinct from the previously treated melanoma. The patient died 9 months later, and a post mortem examination confirmed the diagnosis of a second malignancy, an adenocarcinoma, in the right lung (Fig. 2).

\section{DISCUSSION}

In this case report, a human HLA-B7 gene was delivered by catheter injection into the pulmonary artery associated with metastatic lung nodules of an HLA-B7-negative patient. The treatments were well tolerated. No apparent toxicities were observed. Pulmonary and systemic arterial pressures were normal, biochemical parameters were normal, and no anti-DNA antibodies were detected.

Local drug delivery, including site-specific gene transfer, offers several advantages compared with systemic drug therapy. Local administration of a drug or recombinant DNA can potentially result in high local and low systemic concentrations of an agent, which may minimize systemic toxicities. Several approaches to local delivery are feasible, including implantable subcutaneous pumps, encapsulation of drug within a polymer gel (Langer and Vacanti, 1993), and indwelling vascular catheters (Kennedy et al., 1985; Ensminger, 1993). Prototype catheters have been developed and tested in vivo for local drug delivery into vascular thromboses and for vascular gene transfer, including double balloon catheters (Nabel et al., 1990), porous balloons (Wolinsky and Thung, 1990), catheters coated with polymer gels (Riessen et al., 1993), and autoperfusion catheters. These studies suggest that drugs, such as thrombolytic agents, can be delivered into focal vascular thromboses, achieving high local concentrations of drug and with less toxicity than might be incurred if equivalent doses were delivered systemically. These devices will require future modifications to optimize delivery, minimize local tissue damage, and permit vessel perfusion. Previous methods of local drug delivery are
Table 3. Hematology, Chemistry, and IMMUNOlOGY Parameters Before and AfTer Catheter Gene Delivery

\begin{tabular}{|c|c|c|c|c|}
\hline & \multicolumn{2}{|c|}{ Treatment 1} & \multicolumn{2}{|c|}{ Treatment 2} \\
\hline & Pre & Post & Pre & Post \\
\hline \multicolumn{5}{|l|}{ Hematology } \\
\hline Hemoglobin & 10.5 & 10.6 & 10.4 & 11.5 \\
\hline Hematocrit $(\%)$ & 31.8 & 31.3 & 29.4 & 33.7 \\
\hline White blood count & 7.1 & 5.7 & 7.3 & 8.4 \\
\hline Platelet & 258.0 & 232.0 & 276.0 & 317.0 \\
\hline Prothrombin time (sec) & 13.3 & 12.2 & 12.8 & 12.9 \\
\hline $\begin{array}{l}\text { Partial thromboplastin } \\
\text { time (sec) }\end{array}$ & 21.8 & 23.0 & 22.0 & 24.4 \\
\hline \multicolumn{5}{|l|}{ Chemistry } \\
\hline Albumin $(\mathrm{gm} / \mathrm{dl})$ & 3.1 & 3.3 & 3.1 & 3.3 \\
\hline Alkaline phosphatase (IU/l) & 136.0 & 146.0 & 154.0 & 151.0 \\
\hline SGPT (IU/l) & 21.0 & 24.0 & 22.0 & 23.0 \\
\hline Amylase (U/1) & 52.0 & 57.0 & 64.0 & 49.0 \\
\hline SGOT (AST) (IU/l) & 14.0 & 18.0 & 19.0 & 18.0 \\
\hline BUN (mg/dl) & 23.0 & 18.0 & 27.0 & 24.0 \\
\hline Calcium (mg/dl) & 9.2 & 9.0 & 8.9 & 9.4 \\
\hline Chloride $(\mathrm{mEq} / \mathrm{l})$ & 100.0 & 101.0 & 98.0 & 98.0 \\
\hline Cholesterol (mg/dl) & 176.0 & 200.0 & 193.0 & 205.0 \\
\hline $\mathrm{CO}_{2}(\mathrm{mEq} / \mathrm{l})$ & 30.0 & 27.0 & 28.0 & 28.0 \\
\hline Creatine kinase $(\mathrm{mg} / \mathrm{dl})$ & $<20$ & $<20$ & $<20$ & $<20$ \\
\hline Creatinine (mg/dl) & 1.3 & 1.1 & 1.2 & 1.1 \\
\hline Glucose (mg/dl) & 161.0 & 174.0 & 129.0 & 120.0 \\
\hline $\begin{array}{l}\text { Lactate dehydrogenase } \\
\text { (IU/A) }\end{array}$ & 222.0 & 257.0 & 235.0 & 282.0 \\
\hline Phosphorous (mg/dl) & 3.1 & 3.8 & 3.5 & 3.5 \\
\hline Potassium (mEq/l) & 4.1 & 3.8 & 4.2 & 4.4 \\
\hline Total protein $(\mathrm{gm} / \mathrm{dl})$ & 6.2 & 6.6 & 6.3 & 7.3 \\
\hline Sodium $(\mathrm{mEq} / \mathrm{l})$ & 140.0 & 141.0 & 139.0 & 139.0 \\
\hline Total bilirubin (mg/dl) & 0.2 & 0.4 & 0.3 & 0.4 \\
\hline Uric acid (mg/dl) & 6.2 & 5.9 & 6.3 & 5.8 \\
\hline $\begin{array}{l}\text { Angiotensin converting } \\
\text { enzyme }\end{array}$ & 22.6 & 27.5 & 26.5 & 24.2 \\
\hline \multicolumn{5}{|l|}{ Immunology } \\
\hline$\alpha$ DNA & N/D & N/D & N/D & $<2.5$ \\
\hline ESR & N/D & N/D & N/D & 121.0 \\
\hline CH50 & $\mathrm{N} / \mathrm{D}$ & N/D & $N / D$ & $>200$ \\
\hline CRP & N/D & N/D & N/D & 7.7 \\
\hline
\end{tabular}

Hematology, chemistry, and immunology parameters in the patient 1 day before and 1 day after catheter delivery of DNA-liposomes into the right posterior basal segment artery. N.D. indicates values not determined. Although $\mathrm{CH} 50$ was elevated, this and other immunologic values were unchanged from baseline values (see Table 1).

limited, however, by the rapid clearance of drug following restoration of blood flow. Introduction of a recombinant gene into vascular tissue by catheter might provide for a sustained and localized effect of a therapeutic protein.

Transcatheter injection of recombinant genes into selective sites in the vasculature is one approach to the genetic treatment of cancer and/or vascular diseases that provides targeted expression in vivo. Endolumenal vascular gene transfer has been achieved in several animal models, including pigs (Nabel et al. 1990, 1993b), dogs (Lim et al., 1991; Chapman et al., 1992), rabbits (LeClerc et al., 1992; Barr et al., 1994), and rats (Morishita et al., 1993). Direct gene transfer to the vasculature has been well tolerated in animal models using cationic liposomes 

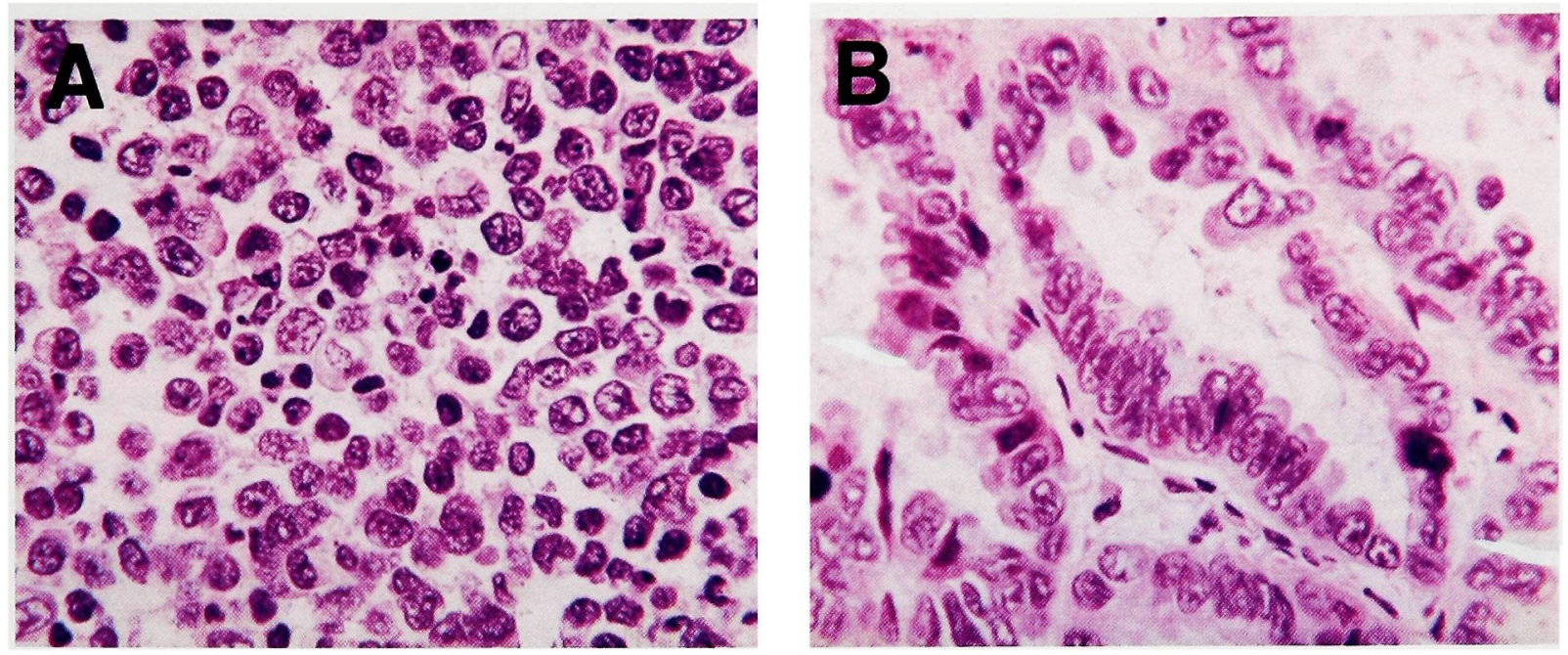

FIG. 2. Histology of representative sections from melanoma lesions in the patient's left or right axilla (A) and adenocarcinoma from the right lower lung (B). Magnification, $400 \times$; hematoxylin and eosin stain.

(Nabel et al., 1992b; San et al., 1993) with minimal toxicities. Recent studies from our laboratory suggest that catheter delivery of DNA to porcine pulmonary arteries using liposomes and adenoviral vectors results in gene expression in pulmonary arteries, capillaries and veins as well as distal alveoli (Muller et al., 1994). While these studies have suggested that endovascular gene transfer is achievable by catheter delivery, its feasibility in humans was not previously tested. The findings in this case report suggest that transcatheter injection of DNA-liposomes into the pulmonary vasculature is a safe and nontoxic approach to the treatment of pulmonary malignancies and/or vascular diseases. These findings suggest that further development of catheters designed to treat focal diseases in humans is warranted and could be applied to the treatment of cancer and vascular diseases.

\section{ACKNOWLEDGMENTS}

We gratefully acknowledge the patients and their families for participation in this study; Mrs. Gail Reisdorph for manuscript preparation; and Dr. Paul Watkins and the General Clinical Research Center for generous assistance. This work was supported in part by National Institutes of Health grants (U01AI33355, G.J.N.; P01 CA59327, A.E.C., G.J.N.; R01 DK42706, E.G.N., and M01-RR00042, General Clinical Research Center). E.G.N. is an Established Investigator of the American Heart Association.

\section{REFERENCES}

AMBROSE, J.A., TORRE, S.R., SHARMA, S.K., ISRAEL, D.H., MONSEN, C.E., WEISS, M., UNTEREKER, W., GRUNWALD, A., MOSES, J. and MARSHALL, J. (1992). Adjunctive throm- bolytic therapy for angioplasty in ischemic rest angina: results of a double-blind randomized pilot study. J. Am. Coll. Cardiol. 20, 1197-1204

BARR, E., CARROLL, J., KALYNYCH, A.M., TRIPATHY, S.K., KOZARSKY, K., WILSON, J.M. and LEIDEN, J.M. (1994). Percutaneous transluminal gene transfer into the heart using replicationdefective recombinant adenovirus. Gene Ther. 1, 51-58.

CHAPMAN, G.D., LIM, C.S., GAMMON, R.S., CULP, S.C., DESPER, S., BAUMAN, R.P., SWAIN, J.L. and STACK, R.S. (1992). Gene transfer into coronary arteries of intact animals with a percutaneous balloon catheter. Circ. Res. 71, 27-33.

ENSMINGER, W.D. (1993). Regional chemotherapy. Semin. Oncol. 20, 3-11.

GAO, X., and HUANG, L. (1991). A novel cationic liposome reagent for efficient transfection of mammalian cells. Biochem. Biophys. Res. Commun., 179, 280-285

KENEDY, J.W., RITCHIE, J.L., DAVIS, K.B., STADIUS, M.L., MAYNARD, C. and FRITZ, J.K. (1985). The western Washington randomized trial of intracoronary streptokinase in acute myocardial infarction. A 12-month follow-up report. N. Engl. J. Med. 312, 1073-1078.

LANGER, R., and VACANTI, J.P. (1993). Tissue engineering. Science 260, 920-925.

LECLERC, G., GAL, D., TAKESHITA, S., NIKOL, S., WEIR, L. and ISNER, J.M. (1992). Percutaneous arterial gene transfer in a rabbit model. Efficiency in normal and balloon-dilated atherosclerotic arteries. J. Clin. Invest. 90, 936-944.

LIM, C.S., CHAPMAN, G.D.,GAMMON, R.S., MUHLESTEIN, J.B., BAUMAN, R.P., STACK, R.S. and SWAIN, J.L. (1991). Direct in vivo gene transfer into the coronary and peripheral vasculatures of the intact dog. Circulation 83, 2007-2011.

MORISHITA, R., GIBBOAS, G.H., KANEDA, Y., OGIHARA, T and DZAU, V.J. (1993). Novel and effective gene transfer technique for study of vascular renin angiotensin system. J. Clin. Invest. 91, 2580-2585.

MULLER, D.W.M., GORDON, D., SAN H., YANG, Z.Y., POMPILI, V.J., NABEL, G.J. and NABEL, E.G. (1994). Cathetermediated pulmonary vascular gene transfer and expression. (submitted).

NABEL, E.G., PLAUTZ, G., and NABEL, G.J. (1990). Site-specific 
gene expression in vivo by direct gene transfer into the arterial wall. Science 249, 1285-1288.

NABEL, G.J., CHANG, A., NABEL, E.G., PLAUTZ, G., FOX, B.A., HUANG, L. and SHU, S. (1992a). Clinical protocol. Immunotherapy of malignancy by in vivo gene transfer into tumors. Hum. Gene Ther. 3, 399-410.

NABEL, E.G., GORDON, D., XANG, Z.-Y., XU, L., SAN, H., PLAUTZ, G.E., GAO, X., HUANG, L. and NABEL, G.J. (1992b). Gene transfer in vivo with DNA-liposome complexes: Lack of autoimmunity and gonadal localization. Hum. Gene Ther. 3, 649-656.

NABEL, G.J., NABEL, E.G., YANG, Z., FOX, B., PLAUTZ, G., GAO, X., HUANG, L., SHU, S., GORDON, D. and CHANG, A.E. (1993a). Direct gene transfer with DNA liposome complexes in melanoma: Expression, biologic activity and lack of toxicity in humans. Proc. Natl. Acad. Sci. USA 90, 11307-11311.

NABEL, E.G., YANG, Z., PLAUTZ, G., FOROUGH, R., ZHAN, $X$, HAUDENSCHILD, C.C., MACIAG, T. and NABEL, G.J. (1993b). Recombinant fibroblast growth factor-1 promotes intimal hyperplasia and angiogenesis in arteries in vivo. Nature 362, 844846.

PLAUTZ, G.E., YANG, Z.Y., WU, B., GAO, X., HUANG, L. and NABEL, G.J. (1993). Immunotherapy of malignancy by in vivo gene transfer into tumors. Proc. Natl. Acad. Sci. USA 90, 46454649 .
RIESSEN, R., RAHIMIZADEH, H., BLESSING, E., TAKESHITA, S., BARRY, J.J. and ISNER, J.M. (1993). Arterial gene transfer using pure DNA applied directly to a hydrogel-coated anioplasty balloon. Hum. Gene Ther. 4, 749-758.

SAN, H., YANG, Z.Y., POMPILI, V.J., JAFFE, M.L., PLAUTZ, G.E., XU, L., FELGNER, J.H., WHEELER, C.J., FELGNER, P.L., GAO, X., HUANG, L., GORDON, D., NABEL, G.J. and NABEL, E.G. (1993). Safety and short-term toxicity of a novel cationic lipid formulation for human gene therapy. Hum. Gene Ther. 4, 781-788.

WOLINSKY, H., and THUNG, S.N. (1990). Use of a perforated balloon catheter to deliver concentrated heparin into the wall of the normal canine artery. J. Am. Coll. Cardiol. 15, 475-481.

\section{Address reprint requests to: Dr. Elizabeth G. Nabel University of Michigan MSRB II, Room 3560 1150 W. Medical Center Drive Ann Arbor, MI 48109-0688}

Received for publication March 1, 1994; accepted after revision May 9, 1994. 
This article has been cited by:

1. Leifu Jiang, Rozenn Quarck, Stefan Janssens, Peter Pokreisz, Maurits Demedts, Marion Delcroix. 2006. Effect of adenovirus-mediated gene transfer of nitric oxide synthase on vascular reactivity of rat isolated pulmonary arteries. Pflügers Archiv - European Journal of Physiology 452:2, 213-221. [CrossRef]

2. Qing Zeng, Peter M. Kanter, Rajiv Dhir, William E. Gooding, Leaf Huang, Jennifer Rubin Grandis. 2002. Lack of toxicity of EGFR antisense gene therapy. Journal of Experimental Therapeutics and Oncology 2:3, 174-186. [CrossRef]

3. Leonard Mohr, Seung-Kew Yoon, Simon J. Eastman, Q. Chu , Ronald K. Scheule, Pier P. Scaglioni , Michael Geissler, Tobias Heintges, Hubert E. Blum , Jack R. Wands . 2001. Cationic Liposome-Mediated Gene Delivery to the Liver and to Hepatocellular Carcinomas in MiceCationic Liposome-Mediated Gene Delivery to the Liver and to Hepatocellular Carcinomas in Mice. Human Gene Therapy 12:7, 799-809. [Abstract] [PDF] [PDF Plus]

4. Chong-Kook Kim, Kh. H Haider, Soo-Jeong Lim. 2001. Gene medicine: A new field of molecular medicine. Archives of Pharmacal Research 24:1, 1-15. [CrossRef]

5. Sharon C. Francis, Michael J. Katovich, Craig H. Gelband, Mohan K. Raizada. 2001. Gene Therapy in Cardiovascular Disease. American Journal of PharmacoGenomics 1:1, 55-66. [CrossRef]

6. Lorena Baccaglini, A. T. M. Shamsul Hoque, Robert B. Wellner, Corinne M. Goldsmith, Robert S. Redman, Vidya Sankar, Albert Kingman, Kerry M. Barnhart, Carl J. Wheeler, Bruce J. Baum. 2001. Cationic liposome-mediated gene transfer to rat salivary epithelial cellsin vitro andin vivo. The Journal of Gene Medicine 3:1, 82-90. [CrossRef]

7. Gaetano Giammona, Gennara Cavallaro, Giovanna Pitarresi, Elisa Pedone. 2000. Cationic copolymers of ?,?-poly-(N-2-hydroxyethyl)-DL-aspartamide (PHEA) and ?,?-polyasparthylhydrazide (PAHy): synthesis and characterization. Polymer International 49:1, 93-98. [CrossRef]

8. Suezanne E. Parker, Flavia Borellini, Martin L. Wenk, Peter Hobart, Stephen L. Hoffman, Richard Hedstrom , Thong Le, Jon A. Norman . 1999. Plasmid DNA Malaria Vaccine: Tissue Distribution and Safety Studies in Mice and RabbitsPlasmid DNA Malaria Vaccine: Tissue Distribution and Safety Studies in Mice and Rabbits. Human Gene Therapy 10:5, 741-758. [Abstract] [PDF] [PDF Plus]

9. Marilyn E. Ferrari, Cuong M. Nguyen, Olivier Zelphati, Yali Tsai, Philip L. Felgner. 1998. Analytical Methods for the Characterization of Cationic Lipid-Nucleic Acid ComplexesAnalytical Methods for the Characterization of Cationic Lipid-Nucleic Acid Complexes. Human Gene Therapy 9:3, 341-351. [Abstract] [PDF] [PDF Plus]

10. Alessandra Boletta, Ariela Benigni, Jens Lutz, Giuseppe Remuzzi, Marco R. Soria, Lucia Monaco. 1997. Nonviral Gene Delivery to the Rat Kidney with PolyethylenimineNonviral Gene Delivery to the Rat Kidney with Polyethylenimine. Human Gene Therapy 8:10, 1243-1251. [Abstract] [PDF] [PDF Plus]

11. Koicni Takakuwa, Kazuyuki Fujita, Akira Kikuchi, Susumu Sugaya, Tetsuro Yahata, Hiroshi Aida, Takumi Kurabayashi, Isao Hasegawa, Kenichi Tanaka. 1997. Direct Intratumoral Gene Transfer of the Herpes Simplex Virus Thymidine Kinase Gene with DNA-liposome Complexes: Growth Inhibition of Tumors and Lack of Localization in Normal Tissues. Cancer Science 88:2, 166-175. [CrossRef]

12. Margreet A. Wolfert, Etienne H. Schacht, Veska Toncheva, Karel Ulbrich, Ola Nazarova, Leonard W. Seymour. 1996. Characterization of Vectors for Gene Therapy Formed by Self-Assembly of DNA with Synthetic Block Co-PolymersCharacterization of Vectors for Gene Therapy Formed by Self-Assembly of DNA with Synthetic Block Co-Polymers. Human Gene Therapy 7:17, 2123-2133. [Abstract] [PDF] [PDF Plus]

13. Dominique J. Stephan, Zhi-Yong Yang, Hong San, Robert D. Simari, Carl J. Wheeler, Philip L. Felgner, David Gordon, Gary J. Nabel, Elizabeth G. Nabel. 1996. A New Cationic Liposome DNA Complex Enhances the Efficiency of Arterial Gene Transfer In VivoA New Cationic Liposome DNA Complex Enhances the Efficiency of Arterial Gene Transfer In Vivo. Human Gene Therapy 7:15, 1803-1812. [Abstract] [PDF] [PDF Plus]

14. Lindsay A. Schwarz, Jennifer L. Johnson, Melanie Black, Seng H. Cheng, Michael E. Hogan, J. Clifford Waldrep. 1996. Delivery of DNA-Cationic Liposome Complexes by Small-Particle AerosolDelivery of DNA-Cationic Liposome Complexes by Small-Particle Aerosol. Human Gene Therapy 7:6, 731-741. [Abstract] [PDF] [PDF Plus]

15. GARY J. NABEL, ZHI-YONG YANG, ELIZABETH G. NABEL, KEITH BISHOP, MAGDA MARQUET, PHILIP L. FELGNER, DAVID GORDON, ALFRED E. CHANG. 1995. Direct Gene Transfer for Treatment of Human Cancer. Annals of the New York Academy of Sciences 772:1 DNA Vaccines, 227-231. [CrossRef] 
16. PHILIP L. FELGNER, YALI J. TSAI, LORETTA SUKHU, CARL J. WHEELER, MARSTON MANTHORPE, JOHN MARSHALL, SENG H. CHENG. 1995. Improved Cationic Lipid Formulations for In Vivo Gene Therapy. Annals of the New York Academy of Sciences 772:1 DNA Vaccines, 126-139. [CrossRef]

17. SANJAY ASRANI, SALVATORE D'ANNA, HAYAT ALKAN-ONYUKSEL, WEIJUN WANG, DAWN GOODMAN, RAN ZEIMER. 1995. Systemic Toxicology and Laser Safety of Laser Targeted Angiography with Heat Sensitive LiposomesSystemic Toxicology and Laser Safety of Laser Targeted Angiography with Heat Sensitive Liposomes. Journal of Ocular Pharmacology and Therapeutics 11:4, 575-584. [Abstract] [PDF] [PDF Plus] 